\title{
Efficient indoor radio channel modeling based on integral geometry
}

\section{Doctoral Thesis}

\section{Author(s):}

Hansen, Jan Carsten

Publication date:

2003

Permanent link:

https://doi.org/10.3929/ethz-a-004495443

Rights / license:

In Copyright - Non-Commercial Use Permitted 
Diss. ETH No. 14938

\title{
Efficient Indoor Radio Channel Modeling Based on Integral Geometry
}

\author{
A dissertation submitted to the \\ Swiss Federal Institute of Technology Zurich \\ for the degree of \\ Doctor of Technical Sciences
}

\author{
presented by \\ JAN HANSEN \\ Dipl.-Phys., Universität Freiburg, Germany \\ born 1 April 1973 \\ citizen of \\ Bochum, Germany
}

accepted on the recommendation of

Prof. Dr. P. E. Leuthold, examiner

Prof. Dr. R. Mathar, co-examiner

Prof. Dr. H. Bölcskei, co-examiner 


\section{Abstract}

This thesis presents a novel concept of stochastic radio channel modeling. It subdivides radio channel modeling into two tasks: the description of wave propagation within given deterministic surroundings and the characterization of the key geometrical properties of these surroundings. Based on this approach, an indoor radio channel model in the frequency range of 2.5 to $60 \mathrm{GHz}$ is developed. The model is completely analytical. It describes the indoor radio channel in dependence on a set of key parameters: the frequency, the antenna characteristics, the pathloss exponent, an average reflection coefficient of the investigated environment, the spatial distribution of the transmitter and the receiver and their minimum distance to each other, and the volume and surface area of the domain in which transmitter and receiver are located. For a system designer, these quantities are easily accessible; only minimum knowledge about the investigated building and the communication system is required. For the derivation of the channel model, geometrical methods are combined with ray optical prin-

ciples. For three different communication systems - WLANs with fixed and random position of the access point, and Ad-Hoc networks with no hierarchy - the mean pathloss (MPl) between two communicating users is calculated in dependence on the above-mentioned parameters. The MPl itself is important; if it is, for instance, used to describe the power of unintentionally received signals, it models the average interference power level within a wireless network. It is furthermore essential for the derivation of the mean and the standard deviation of the large-scale distribution of the pathloss. Since the pathloss is known to be lognormal distributed, its mean and standard deviation suffice for a complete characterization of its statistics. Geometrical arguments are presented which demonstrate why the lognormal distribution provides a suitable description. In addition to the large-scale distribution of the pathloss, the power delay profile (PDP) is derived for a single room environment. It is proven that the PDP in such simple surroundings is exponential. An analytical expression for the delay spread is extracted which is a suitable upper bound for the delay spread in more complicated environments.

The combination of the different results yields a complete description of the frequency selective, Rayleigh fading indoor radio channel. The underlying distribution functions - lognormal for the large-scale variations 
of the received power and exponential for the PDP - have been long known on an empirical basis. In this thesis, they are presented in analytical form in dependence on a few, easily accessible key parameters. The derived channel model is verified against simulated and measured data and implemented as a MATLAB code. 


\section{Kurzfassung}

Die vorliegende Arbeit behandelt ein neuartiges Konzept zur stochastischen Kanalmodellierung. Das vorgeschlagene Konzept trennt die Kanalmodellierung in zwei Teile: Zunächst muss die Wellenausbreitung in hinreichend genau determinierten Umgebungen beschrieben werden. Hiernach werden die für die Wellenausbreitung wichtigen geometrischen Eigenschaften bestimmt.

Auf dieser Grundlage wird ein Modell für den Funkkanal innerhalb von Gebäuden entwickelt. Das Modell ist rein analytisch und soll für den Frequenzbereich von 2.5 bis $60 \mathrm{GHz}$ gelten. Es beschreibt den Funkkanal anhand einiger wesentlicher Parameter: der Frequenz, der Antennencharakteristik, einer in der englischen Fachliteratur als pathloss bekannten skalaren Grösse zur Charakterisierung der Wellenausbreitung, weitherhin anhand des durchschnittlichen Reflexionsverlustes an Wänden des Gebäudes, der räumlichen Verteilungen von Sender und Empfänger und ihres minimalen Abstands. Schliesslich werden das Volumen und die Oberfläche des Gebietes benötigt, in dem sich Sender und Empfänger befinden. Alle diese Grössen sind für einen Systemdesigner sehr einfach und mit nur minimaler Kenntnis des untersuchten Gebäudes und des betrachteten Kommunikationssystems abzuschätzen.

Für die Herleitung des Kanalmodells werden geometrische Verfahren mit strahlenoptischen Methoden verknüpft. Drei unterschiedliche Kommunikationssysteme werden behandelt: WLANs mit fester und zufälliger Position des Zugangsknotens (Access Points), und Ad-Hoc Netzwerke ohne jegliche Hierarchie. Der Mittelwert des Leistungsverlustes im Kanal wird für zwei miteinander kommunizierende Benutzer in Abhängigkeit der oben aufgezählten Parameter berechnet. Dieser Wert ist bereits für sich genommen von grosser Wichtigkeit, da er z. B. die mittlere Interferenzleistung darstellt, die ein Störer in einem drahtlosen Netzwerk erzeugt. Er ist ausserdem die Grundlage für die Herleitung des Mittelwertes und der Standardabweichung der Verteilung des globalen Schwundes. Da bekannt ist, dass es sich hierbei um eine Lognormalverteilung handelt, genügt die Kenntnis dieser beiden Werte für eine vollständige Charakterisierung. Mit Hilfe geometrischer Argumente wird gezeigt, warum die Lognormalverteilung eine passende Beschreibung darstellt.

Ausserdem wird das Verzögerungs-Leistungsdichteprofil (Power Delay 
Profile, PDP) innerhalb eines einzelnen Raumes hergeleitet. Die Herleitung ergibt eine Exponentialfunktion. Automatisch resultiert daraus ein analytischer Ausdruck für die Verzögerungsspreizung (Delay Spread, DS), der als obere Schranke für den DS von komplizierteren Umgebungen verwendet werden kann.

Zusammen ergeben diese unterschiedlichen Ergebnisse eine vollständige Charakterisierung des frequenzselektiven Rayleigh Schwundkanals innerhalb von Gebäuden. Die entsprechenden Verteilungsfunktionen - lognormal für die globale Schwundverteilung und exponentiell für das PDP - sind aufgrund empirisch gewonnener Resultate bereits bekannt. In dieser Arbeit werden sie als analytische Ausdrücke angegeben, die von wenigen, wesentlichen und einfach zu ermittelnden Parametern abhängen. Das entwickelte Modell wird anhand von simulierten und gemessenen Daten überprüft und ist mit Hilfe der Programmiersprache MATLAB als Computerprogramm implementiert. 